\title{
Genes and hormones: sex differences in myocardial hypertrophy
}

\author{
Ute Seeland · Vera Regitz-Zagrosek
}

Published online: 16 February 2013

(C) Springer-Verlag Berlin Heidelberg 2013

\begin{abstract}
Female hearts develop a more favorable physiological form of myocardial remodeling when subjected to pressure or volume overload than male hearts involving the synergistic activity of several cellular-based protective pathways induced by estrogen signaling via estrogen receptors (ERs), influencing mitochondrial function, and myocardial energy metabolism. In contrast, testosterone induces matrix remodeling and growth factor signaling via androgen receptors (AR) and contributes to eccentric remodeling. This review focuses on sex differences in ventricular morphology and function and in myocardialsignaling pathways in myocardial hypertrophy $(\mathrm{MH})$ to understand protective mechanisms or alternatively suppressed or avoided maladaptive-signaling pathways in the female sex.
\end{abstract}

Keywords Myocardial hypertrophy - Sex differences · Estrogen $\cdot$ Testosterone $\cdot$ Sex hormone receptor

\section{Gene und Hormone - Geschlechterunterschiede bei der Myokardhypertrophie}

$\begin{array}{ll}\text { List of abbreviations } \\ \text { AS } & \text { Aortic stenosis } \\ \text { AR } & \text { Androgen receptor } \\ \text { AVR } & \text { Aortic valve replacement } \\ \text { E2 } & 17 \beta \text {-estradiol } \\ \text { ECM } & \text { Extracellular matrix } \\ \text { ER } & \text { Estrogen receptor } \\ \text { HF } & \text { Heart failure } \\ \text { LVH } & \text { Left ventricular hypertrophy } \\ \text { MH } & \text { Myocardial hypertrophy } \\ \text { MMP } & \text { Matrix metalloproteinases } \\ \text { NO } & \text { Nitric oxide } \\ \text { PO } & \text { Pressure overload } \\ \text { PPAR } & \text { Peroxisome proliferator-activated receptor } \\ \text { PGC-1 } & \text { PPAR- } \gamma \text { coactivator 1 } \\ \text { TAC } & \text { Transverse aortic constriction } \\ \text { TGF } & \text { Transforming growth factor }\end{array}$

\section{Introduction}

Average life expectancy is better in women than in men and in most of female animal models compared with the males. Evidently, in the female aging heart apoptosis and fibrosis as well as hypertrophy are less pronounced than in the aging male heart. These functional and survival advantages for women could be based on different gene products of sexual chromosomes as well as different morphological and metabolic effects of sex hormones and their receptors. Animal models for physiological and pathological myocardial hypertrophy (MH) and heart failure (HF) [1], in combination with cell-specific and/or cell-inducible genetic deletion 
or over-expression of hormone receptors, have been used to analyze hormone-related and chromosome-based sex differences. It has yet to be determined whether the mechanisms observed in animal models can be applied to the human heart or not.

\section{Physiological myocardial hypertrophy}

Physical exercises as well as pregnancy are two major conditions associated with physiological concentric $\mathrm{MH}$ due to adaptation to pressure or volume overload or hormonal effects. Even so these conditions differ in a number of changes in gene expression, they also have great similarities [2]. Both are characterized by $\mathrm{MH}$ with normal or enhanced cardiac function. There is no evidence of interstitial fibrosis and apoptosis. Expression of fetal genes such as major histocompatibility complex heavy-chain, atrial natriuretic peptide precursor, phospholamban, and sarcoplasmatic reticulum ATPase are not increased. Mechanical and hormonal effects induce myocardial adaptation, e.g., myocyte hypertrophy without major influence on myocyte gene expression patterns. Reversibility of myocardial adaptation is very common. However, providing pathological stimuli, transition to pathological $\mathrm{MH}$ may occur in these conditions as well. In particular, the pregnant heart is prone to greater damage when exposed to ischemic injury than the normal heart [3].

\section{Sex-specific ventricular morphology and function}

Sex steroid hormones such as $17 \beta$-estradiol (E2) and testosterone affect cardiac growth. The effects are mainly mediated by their nuclear receptors-ER $\alpha, \mathrm{ER} \beta$, and androgen receptors (AR), shown in rodent as well as human hearts. These receptors are functionally active not only in myocytes, but also in fibroblasts, vascular endothelial cells, and smooth muscle cells of rodents and humans [4-6]. ER $\alpha$ and $\beta$ are expressed in human hearts and regulated in pathological conditions $[7,8]$. ERs act as transcription factors in a ligand-dependent manner and bind as hetero- or homodimers to hormone-responsive DNA elements initiating the transcription of hormone-sensitive genes. The activity of ERs is modulated by alternative intracellular-signaling pathways downstream of peptide growth factors and neurotransmitters. Recent research suggests a role for ER in epigenetic DNA modifications. ER can act together with histone acetylases to modify gene expression. ERs may also be active in immature mice before gonadal production of sex hormones as well as in ovariectomized adult mice. This sex hormone ligand-independent activation of ERs is consistent with the fact that ER-mediated effects are not limited to premeno- pausal women, but may play a role in aging women and in men [9]. Furthermore, white fat synthesizes estrogens and plays a role in local and systematic signaling in men.

Changes in left-ventricular mass in response to age and hypertrophic stimuli are different in women and men. The decline in myocyte number and increase in myocyte size is more pronounced in men [10]. In general, normal female hearts are smaller and stiffer than male hearts [11]. This may favor a greater tendency in women to develop diastolic instead of or prior to systolic dysfunction and HF with preserved ejection fraction (HF-PEF). Major risk factors for HF-PEF include aging, hypertension, obesity, diabetes, and ischemia. Ischemia may play a greater role in men, hypertension and diabetes in women.

Under pressure overload (PO), women are more prone to develop concentric $\mathrm{MH}$ with thickening of the left ventricle wall due to addition of sarcomeres in parallel and an increase in myocyte cell width. Men tend to develop eccentric hypertrophy with thinner ventricular walls and larger cavities due to the addition of sarcomeres in series increasing myocyte cell length. Sex differences in cardiac pathology following PO are observed in particular in elderly patients with aortic stenosis (AS). Women develop a more concentric form of hypertrophy with smaller ventricular diameters and less ventricular dilatation with better systolic ventricular function than men [12]. Left ventricular mass as well as ventricular and arterial stiffness increase with age in both sexes, but the increase is more striking in women, especially in the postmenopausal years. For review see Scantlebury and Borlaug [13].

A number of molecular mechanisms can contribute to the gender differences in $\mathrm{MH}$. Effects of estrogen provide benefit to premenopausal women, and the loss of its protective mechanisms may render the heart of postmenopausal women more vulnerable. The underlying molecular mechanisms include E2 effects, e.g., on collagen synthesis and degradation, inhibition of the activated renin-angiotensin system following pathological conditions as well as gender differences in myocardial calcium handling and in the nitric oxide (NO) system. According to Kim et al. [14], E2 also directly protects cardiomyocytes. It inhibits hypoxia/ reoxygenation $(\mathrm{H} / \mathrm{R})$-induced apoptosis of cultured rat cardiomyocytes via estrogen receptor (ER) signaling. E2-activated phosphoinositol-3 kinase (PI3K) was found to inhibit mitochondrial-reactive oxygen species (ROS) formation, leading to modification of downstream p38 signaling and cardiomyocyte survival. The rapid nongenomic effects and the long-term effects of estrogens on vasculature are described elsewhere [15].

Cardiac hypertrophy in response to PO due to hypertension or AS is not only characterized by increased cardiomyocyte diameter, but also by increased interstitial fibrosis. Estrogen and testosterone modulate extracellular matrix 
(ECM) turnover, which contributes to the structural and functional integrity of the heart. Estrogen regulates collagen synthesis differently in male and female cardiac fibroblasts [16]. Estrogen also modulates matrix metalloproteinase-2 (MMP-2) via MAPK pathway [17]. In addition, testosterone effects are involved in synthesis of collagen proteins as well as in increased expression and activity of collagen degrading enzymes such as matrix metalloproteinases (MMPs) and contributes to cavity dilatation and rupture after myocardial infarction [18]. Among the various known MMPs, MMP-2 (gelatinase A) plays a dominant role in cardiac remodeling. An increase in MMP-2 expression and activity occurs in PO-, myocardial infarction-, in $\mathrm{MH}$ - and $\mathrm{HF}$ - conditions and is associated with adverse cardiac remodeling [19]. These findings correspond to the fact that extracellular fibrosis is more evident in the aging male human heart compared with female hearts of older age. Furthermore, in surgical biopsies of patients with aortic valve replacement (AVR) gene expression of collagen type I and III and MMP-2 was significantly higher in male than in female patients [20]. Dysregulation of ECM turnover appears to be another potential molecular mechanism to explain sex differences in left ventricular adaptation and remodeling.

\section{Sex-specific myocardial-signaling pathways and myocardial metabolism}

Both ER $\alpha$ and ER $\beta$ are upregulated in human MH. The increase in ER $\alpha$ is similar in both sexes. The induction of $\mathrm{ER} \beta$ is stronger in female than in male hearts and shows a close correlation with ejection fraction (EF) of the left ventricle [7]. Evidence for a dominant and cardioprotective role of ER $\beta$ in the cardiac response to PO has been reported in animal experiments. Angiotensin infusion in female mice resulted in marked hypertrophy of the left ventricle, exacerbated by the loss of ovarian steroid hormones after ovariectomy. Pedram et al. [21] determined the cellular effects of E2 in female mice with marked hypertrophy due to AngII infusion. Hypertrophy was $51 \%$ reduced by the administration of E2. AngII induced a switch of myosin heavy-chain production from alpha to beta, but this was inhibited by E2 via ER $\beta$. AngII-induced ERK activation and calcineurin activity were inhibited by E2 through the betareceptor. E2 substantially prevented ventricular interstitial cardiac fibrosis as induced by AngII. Taking into account all these aspects, E2 mitigates AngII signaling that produces cardiac hypertrophy and fibrosis in female mice. These results underline the important role of E2 regarding cardiomyocyte protection. Studies with $\operatorname{ER} \beta(-/-)$ knockout mice confirm these data. Female ER knockout mice lacking ER $\beta$ responded to transverse aortic constriction (TAC) with a significantly greater increase in $\mathrm{HW} / \mathrm{BW}$ ratio compared with female wild-type (WT) littermates [22]. Echocardiographic measurements of these $\operatorname{ER} \beta(-/-)$ mice by Fliegner et al. [23] revealed the supposed concentric form of hypertrophy in females, while males developed eccentric hypertrophy 9 weeks after TAC surgery. The lack of ER $\beta$ augmented the TAC-induced increase in cardiomyocyte diameter in both sexes. Cardiac fibrosis was more pronounced in male WT/ TAC than in female mice. This difference was abolished in $\operatorname{ER} \beta(-/-)$ mice. The number of apoptotic nuclei increased in both sexes of $\operatorname{ER} \beta(-/-) /$ TAC mice, most prominent in males. The data show that both-female sex and ER $\beta$ attenuate the development of fibrosis and apoptosis, thus slowing the progression to HF in this animal model [23].

To gain better understanding of E2-induced ER $\alpha$ action in the human heart, Mahmoodzadeh et al. [24] identified and functionally analyzed E2-induced interaction partners with ER $\alpha$ in the human heart. The authors identified atrial natriuretic peptide precursor A (NPPA), a well-known cardiac hypertrophy marker, as an ER $\alpha$ interaction partner. The LXXLL motif within NPPA is necessary for its E2-induced interaction with $\mathrm{ER} \alpha$, its action as a corepressor of $\mathrm{ER} \alpha$ and its translocation into the nucleus of human and rat cardiomyocytes. Experiments in a human left ventricular cardiomyocyte cell line showed that NPPA interacts with E2/ER $\alpha$, suppressing the transcriptional activity of ER $\alpha$ on E2-target genes such as NPPA, connexin43, oactinin-2, nuclear factor of activated T-cells, and collagens I and III. These findings may be crucial in physiological and pathological cardiac processes, thereby representing a potential therapeutic target [24].

Expression of the ER $\alpha$ gene in patients with AS is regulated in a disease-dependent manner. In various cell lines and tissues as well as in the human heart, the ER $\alpha$ mRNA is transcribed from multiple promoters. One of them binds $\mathrm{NF}-\kappa \mathrm{B}$ which inhibits transcription. The NF- $\kappa \mathrm{B}$ pathway takes part in a negative regulatory mechanism for the expression of ER $\alpha$ in human heart. Inflammatory stimuli suppress hER $\alpha$ expression via activation and subsequently bind $\mathrm{NF}-\kappa \mathrm{B}$ to the $\mathrm{ER} \alpha$ promoter. In contrast, E2 induced the transcriptional activity of the hER $\alpha$ promoter in human myocardium. This may lead to an interplay between estrogen effects and the pro-hypertrophic and inflammatory responses to $\mathrm{NF}-\kappa \mathrm{B}$ [8]. Testosterone contributes to the inflammatory mechanisms in $\mathrm{MH}$ via activation of $\mathrm{NF}-\kappa \mathrm{B}$ and its dependent target genes [25, 26].

Key experimental findings contributing to our understanding of pathological and physiological heart growth focus on signaling pathways influenced by sex hormones (Fig. 1) [27]. Because of crosstalk and integration of various pathways, signaling cascades involved in cardiac hypertrophy are complex. Since Akt signaling is known to have a greater activity in the female than in the male human heart, the stimulation of this pathway may contribute to sex dif- 
$17 \beta$-Estradiol

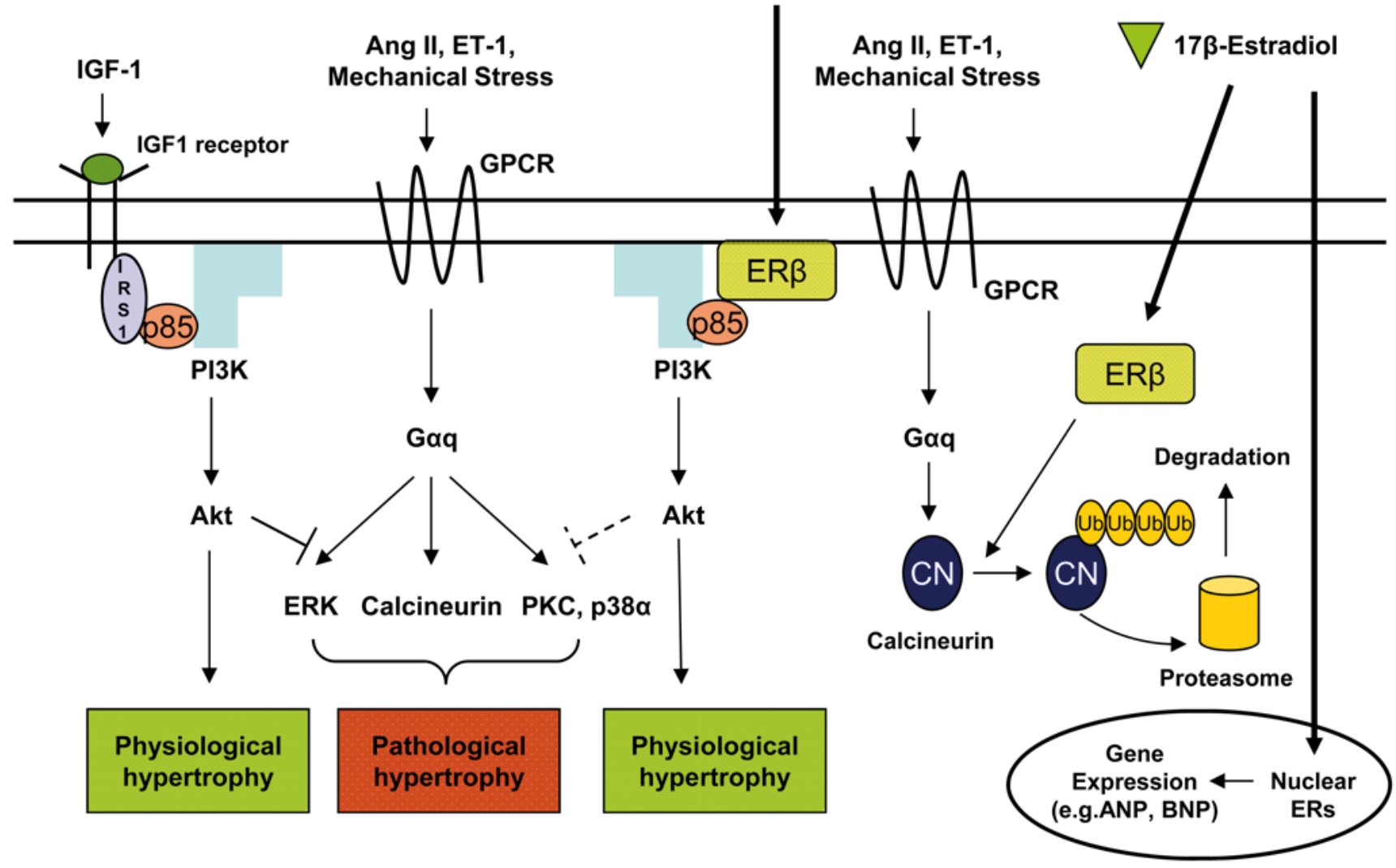

Fig. 1 Signaling cascades involved in estrogen-mediated cardiac hypertrophic responses. Estrogen receptors (ER $\alpha$ and ER $\beta)$ are upregulated in human myocardial hypertophy. The induction of ER $\beta$ is stronger in female than in male hearts. Estrogen acts via PI3K to induce physiological hypertrophy and attenuates pathological signaling cascades. Akt signaling is more active in female hearts. Nuclear ERs alter gene expression to regulate cardiac hypertrophic responses. Ang II

ferences in the development of hypertrophy. Camper-Kirby et al. [28] found higher levels of nuclear-localized Akt, a protein kinase that regulates a broad range of physiological responses including metabolism, gene transcription, and cell survival, in young women relative to comparably aged men or postmenopausal women. Cytosolic localization of phospho-forkhead, a downstream nuclear target of Akt, is also increased in female relative to male mice, suggesting a potential mechanism for cardioprotective nuclear signaling resulting from Akt activation. The activation of Akt in a sex-dependent manner may help explain differences observed in cardiovascular disease risk between the sexes and supports the potential beneficial effects of estrogenic stimulation. Increased activation of the phosphoinositide 3-kinase (PI3K) pathway has been described in mice with swim training. This training had a favorable effect on cardiac function and fibrosis in this PO model [29]. Thus, Akt signaling is more active in female hearts and a putative protective mechanism contributing to physiological $\mathrm{MH}$. angiotensin II, $A N P$ atrial natriuretic peptide, $B N P$ B-type natriuretic peptide, $C N$ calcineurin, $E R$ estrogen receptor, $E R K$ extracellular regulated kinase, ET-1 endothelin-1, GPCR G protein-coupled receptor, $I G F 1$ insulin-like growth factor $1, I R S 1$ insulin receptor substrate 1, $P I 3 K$ phosphoinositide 3-kinase, $P K C$ protein kinase $\mathrm{C}, \mathrm{Ub}$ ubiquitin. (Adapted from [27])

Myocardial function is dependent on substrate utilization and metabolism. Key enzymes in glucose and fatty acid metabolism are regulated by sex hormones [30]. Beneficial effects of estrogens on the lipid profile such as increasing HDL- and decreasing LDL cholesterol play a part in contributing to the lower incidence of cardiovascular disease in premenopausal women. Free fatty acids (FFA) are liberated from triglyceride-rich lipoproteins by lipoprotein lipase (LPL) and are considered to be a principal energy source for the heart. Peroxisome proliferator-activated receptors (PPAR- $\alpha$, PPAR- $\gamma$, and others), a family of nuclear receptors, modulate transcription of key genes in mitochondrial metabolism and control the balance of glucose and fatty acid utilization in the myocardium. The PPAR- $\gamma$ coactivator 1 (PGC-1), which is a central activator of mitochondrial biogenesis and function as well as fatty acid oxidation is regulated by estrogens [30]. PGC-1 gene expression is lower in males compared with females in TAC mice. PPAR- $\alpha$ is a key regulator of FFA catabolism [31]. Gene deletion of 
PPAR- $\alpha$ in animal models with simultaneous modulation of fatty acid utilization (PPAR- $\alpha$ transgenic mice overexpressing LPL in skeletal and cardiac muscle) led to sex-specific phenotypes with HF-related death in male animals and survival in females. Changes in plasma glucose, FFA, lactate, and triglycerides did not clearly account for sex-specific differences in mortality; however, the authors indicated a critical role for PPAR- $\alpha$ in myocardial pump function during fasting $[1,32]$.

A number of pathways that are involved in $\mathrm{MH}$ and are modulated by sex or sex hormones include the insulin-like growth factor/PI3K-axis that may lead to sex-dependent stimulation of nitric oxide synthases (NOSs). Changes in the constitutive endothelial NOS expression and activity are a function of estrogen and hypertrophic status. Stimulation of NOS leads to an increase in NO production under various circumstances depending upon the isoforms and has recently been linked with sex-specific phenotypes. Estrogens are necessary for the highest NOS activity, while PO per se increased total NOS activity in the left ventricle. Estrogen deficiency primarily affects endothelial NOS activity through a mechanism involving caveolin-1 [33].

\section{Sex-specific genomic response and the E2/ERß axis}

Weinberg et al. [34] characterized responses of male and female mouse left ventricles (LV) to PO (TAC) at the genomic level by high-density microarray analysis. Interestingly, a greater number of genes were regulated in response to acute overload than in response to chronic overload, and sex modified these responses.

Two studies were published recently dealing with sexspecific effects and the genomic response on cardiac hypertrophy. Gene expression was regulated in a sex-specific manner 2 weeks after PO in WT mice, despite the fact that sex differences in cardiac morphology and function did not occur at this early time point [35]. Female hearts responded to PO with a better adaptation in cardiac energy metabolism. Genes encoding for mitochondrial function and fatty acid oxidation were less downregulated in female hearts, while a relative upregulation of matrix remodeling- and ribosomal genes was identified in males. These processes have been observed in the early stage of hypertrophy and may represent the molecular basis for the sex-specific functional changes that were found at later stages of PO and left ventricular hypertrophy (LVH). Fliegner et al. [23] analyzed LV samples of male and female WT and $\operatorname{ER} \beta(-/-)$ knockout mice 9 weeks after TAC by microarray and real-time RT-PCR. Gene expression profiling revealed that WT male hearts had a stronger induction of ECM-related genes due to increased MAPK signaling and pathways related to the regulation of the cytoskeleton and a stronger repression of mitochondrial genes than WT female hearts. These pathways, if activated, lead to the induction of fibroblast growth factors and the renin-angiotensin system. Categories and pathways with a significant enrichment of genes and a potential relevance for the development of hypertrophy are shown in Table 1.

In mice with $\mathrm{MH}$ upon $\mathrm{TAC}$, a number of genes related to energy metabolism and mitochondrial function are more downregulated in males compared with females. $\operatorname{ER} \beta(-/-)$ mice exhibited a different global gene expression pattern, which was affected by the genotype and the hypertrophic response. Female $\operatorname{ER} \beta(-/-)$ mice showed a relatively stronger expression of genes involved in ubiquitin-mediated proteolysis, Wnt and p53 signaling (Table 1). Male $\operatorname{ER} \beta(-/-)$ mice were characterized by relatively stronger expression of genes that play a role in the regulation of programmed cell death, cell proliferation, and in transforming growth factor (TGF) signaling (Table 1).

To determine the role of the E2/ER $\beta$ axis in the genomic response to PO-induced hypertrophy, Kararigas et al. [36] used the microarray dataset of female WT and female $\operatorname{ER} \beta(-/-)$ mice after TAC. Data analysis was done for differences in the expression of individual probe sets between female TAC and sham mice followed by comparison of these differences between the two genotypes, WT and $\operatorname{ER} \beta(-/-)$. This approach revealed that the two genotypes have distinct transcriptional profiles. Considerably, more genes were modulated in response to PO induced by TAC in $\operatorname{ER} \beta(-/-)$ mice than in WT mice. The majority of the identified candidates in female ER $\beta(-/-)$ mice were induced, e.g., genes related to inflammatory- and oxidative stress-induced pathways, while those in female WT mice were repressed. The data show that the presence of ER $\beta$ is essential for the strict control of the induction of numerous genes in PO and suggest a repressive role of gene expression for ER $\beta$. The absence of ER $\beta$ leads to a dramatic number of modulated probe sets in response to PO. These data may offer the molecular explanation for the cardioprotective role of ER $\beta$, while ER $\beta$ acquires the role of a gatekeeper of the genomic response of the heart to PO-induced hypertrophy.

\section{Clinical implications}

The most frequent precursor and facilitator of HF in women is $\mathrm{MH}$ due to hypertension or other nonischemic origins; whereas in men, an ischemic etiology predominates [37]. Increased left ventricular mass is an important cardiovascular risk factor for morbidity and has a greater impact on survival in women than in men [38]. The adaptations in men and women are different as described above. Understanding these differences could result in novel therapies that would be beneficial for both sexes. 
Table 1 Regulated pathways in WT and ER $\beta(-/-) /$ TAC mice. (Copyright American Physiological Society, with permission, [23])

\begin{tabular}{|c|c|c|c|}
\hline $\begin{array}{l}\text { Gene ontology category or } \\
\text { KEGG pathway }\end{array}$ & & Count $(\%)$ & $P$ value \\
\hline & Subset a: relative higher expression in $W T$ females & & \\
\hline \multirow[t]{2}{*}{ BP } & Electron transport & $12(3.3)$ & 0.055635 \\
\hline & Oxidative phosphorylation & $4(1.1)$ & 0.087204 \\
\hline $\mathrm{CC}$ & Mitochondrial part & $14(3.9)$ & 0.004262 \\
\hline MP & Electron carrier activity & $8(2.2)$ & 0.031429 \\
\hline \multirow[t]{2}{*}{ KEGG } & Oxidative phosphorylation & $9(2.5)$ & 0.001461 \\
\hline & Subset b: relative higher expression in WT males & & \\
\hline \multirow[t]{3}{*}{ BP } & Regulation of cell proliferation & $24(4.4)$ & 0.000021 \\
\hline & Biopolymer metabolic process & $140(25.4)$ & 0.000424 \\
\hline & Muscle fiber development & $7(1.3)$ & 0.005933 \\
\hline \multirow[t]{2}{*}{$\mathrm{CC}$} & Intracellular part & $255(46.5)$ & $<0.000001$ \\
\hline & Cytoskeletal part & $20(3.6)$ & 0.085629 \\
\hline \multirow[t]{2}{*}{ MP } & Cytoskeletal protein binding & $17(3.1)$ & 0.0207 \\
\hline & Growth factor binding & $5(0.9)$ & 0.035409 \\
\hline \multirow[t]{3}{*}{ KEGG } & MAPK-signaling pathway & $14(2.5)$ & 0.020864 \\
\hline & Regulation of actin cytoskeleton & $11(2.0)$ & 0.059141 \\
\hline & Subset c: relative higher expression in $E R \beta(-/-)$ females & & \\
\hline \multirow[t]{3}{*}{ BP } & Biopolymer metabolic process & $160(32.1)$ & $<0.000001$ \\
\hline & Cell cycle process & $25(5.0)$ & 0.001884 \\
\hline & Regulation of programmed cell death & $19(3.8)$ & 0.010344 \\
\hline \multirow[t]{2}{*}{$\mathrm{CC}$} & Intracellular part & $259(52.1)$ & $<0.000001$ \\
\hline & Ubiquitin ligase complex & $5(1.0)$ & 0.020774 \\
\hline MP & Ubiquitin protein ligase activity & $16(3.2)$ & $<0.000001$ \\
\hline \multirow[t]{4}{*}{ KEGG } & Ubitquitin-mediated proteolysis & $17(3.4)$ & $<0.000001$ \\
\hline & Wnt-signaling pathway & $11(2.2)$ & 0.003519 \\
\hline & p53-signaling pathway & $5(1.0)$ & 0.082801 \\
\hline & Subset $d$ : relative higher expression in ER $\beta(-/-)$ males & & \\
\hline \multirow[t]{3}{*}{ BP } & Biopolymer metabolic process & $102(27.7)$ & 0.000064 \\
\hline & Regulation of cell proliferation & $16(4.4)$ & 0.000719 \\
\hline & Regulation of programmed cell death & $16(4.4)$ & 0.006024 \\
\hline $\mathrm{CC}$ & Intracellular part & $190(51.6)$ & $<0.000001$ \\
\hline MP & Cytoskeletal protein binding & $11(3.0)$ & 0.084934 \\
\hline \multirow[t]{2}{*}{ KEGG } & Dentatorubropallidoluysian & $3(0.8)$ & 0.027815 \\
\hline & Chronic myeloid leukemia & $5(1.4)$ & 0.044170 \\
\hline
\end{tabular}

$B P$ biological process, $C C$ cellular compartment, $M P$ molecular process, $K E G G$ kyoto encyclopedia genes and genomes, $W T$ wild type

Sex differences are well described in MH due to AS. Women with AS develop greater wall thickness and more concentric LV hypertrophy and have LVs with smaller diameters; whereas, men more commonly demonstrate eccentric remodeling. Estrogen may limit the development of $\mathrm{MH}$ [39]. At present, there is no therapeutic exploitation of this potential approach, since estrogens have major side effects in men and have been shown to lead to an increase in cardiovascular risk and breast cancer in women [40]. However, novel therapeutic approaches with specific modulators of sex-specific signaling such as selective estrogen receptor modulators (SERM), ER $\alpha$ - or ER $\beta$-specific agonists, or other substances that interfere with sex-specific pathways could be used to specifically target the beneficial mechanisms [41].

Studies focusing on clinical response to the reduction of the transvalvular gradient after transcatheter aortic valve implantation (TAVI) found that regression of hypertrophy occurred in men and women, but female sex was an independent predictor of early improvement of the ejection fraction (EF) after AVR [42]. C-reactive protein and interleukin- 6 were elevated at baseline more in men than in women, decreased after TAVI, and normalized at 3 months only in women. Peri-interventional complications and 3-months mortality were not different in this prospectively analyzed cohort of TAVI patients. Stangl et al. [42] conclude 
that women and men benefit from TAVI with sex differences involving the recovery response of the left ventricle after TAVI. Whether the less invasive approach of TAVI compared with conventional surgery is particularly beneficial for women or not has to be discussed with the help of future studies.

Acknowledgments This article is part of a supplement sponsored by Lilly Deutschland GmbH and Daiichi Sankyo Deutschland GmbH.

Conflict of interest The authors declare that there is no actual or potential conflict of interest in relation to this article.

\section{References}

1. Djouadi F, Weinheimer CJ, Saffitz JE, Pitchford C, Bastin J, Gonzalez FJ, Kelly DP (1998) A gender-related defect in lipid metabolism and glucose homeostasis in peroxisome proliferator-activated receptor alpha- deficient mice. J Clin Invest 102(6):1083-1091

2. Leinwand LA (2003) Sex is a potent modifier of the cardiovascular system. J Clin Invest 112(3):302-307. doi:1007/ s00395-012-0271-7

3. Li J, Umar S, Iorga A, Youn JY, Wang Y, Regitz-Zagrosek V, Cai H, Eghbali M (2012) Cardiac vulnerability to ischemia/reperfusion injury drastically increases in late pregnancy. Basic Res Cardiol 107(4):271

4. Karas RH, Patterson BL, Mendelsohn ME (1994) Human vascular smooth muscle cells contain functional estrogen receptor. Circulation 89(5):1943-1950

5. Venkov CD, Rankin AB, Vaughan DE (1996) Identification of authentic estrogen receptor in cultured endothelial cells. A potential mechanism for steroid hormone regulation of endothelial function. Circulation 94(4):727-733

6. Grohe C, Kahlert S, Lobbert K, Stimpel M, Karas RH, Vetter H, Neyses L (1997) Cardiac myocytes and fibroblasts contain functional estrogen receptors. FEBS Lett 416(1):107-112

7. Nordmeyer J, Eder S, Mahmoodzadeh S, Martus P, Fielitz J, Bass J, Bethke N, Zurbrugg HR, Pregla R, Hetzer R, Regitz-Zagrosek $\mathrm{V}$ (2004) Upregulation of myocardial estrogen receptors in human aortic stenosis. Circulation 110(20):3270-3275

8. Mahmoodzadeh S, Eder S, Nordmeyer J, Ehler E, Huber O, Martus P, Weiske J, Pregla R, Hetzer R, Regitz-Zagrosek V (2006) Estrogen receptor alpha up-regulation and redistribution in human heart failure. Faseb J 20(7):926-934

9. Ciana P, Raviscioni M, Mussi P, Vegeto E, Que I, Parker MG, Lowik C, Maggi A (2003) In vivo imaging of transcriptionally active estrogen receptors. Nat Med 9(1):82-86

10. Olivetti G, Giordano G, Corradi D, Melissari M, Lagrasta C, Gambert SR, Anversa P (1995) Gender differences and aging: effects on the human heart. J Am Coll Cardiol 26(4):1068-1079

11. Hayward CS, Kalnins WV, Kelly RP (2001) Gender-related differences in left ventricular chamber function. Cardiovasc Res 49(2):340-350

12. Villari B, Campbell SE, Schneider J, Vassalli G, Chiariello M, Hess OM (1995) Sex-dependent differences in left ventricular function and structure in chronic pressure overload. Eur Heart J 16(10):1410-1419

13. Scantlebury DC, Borlaug BA (2011) Why are women more likely than men to develop heart failure with preserved ejection fraction? Curr Opin Cardiol 26(6):562-568. doi:10.1097/ HCO.0b013e32834b7faf
14. Kim JK, Pedram A, Razandi M, Levin ER (2006) Estrogen prevents cardiomyocyte apoptosis through inhibition of reactive oxygen species and differential regulation of $\mathrm{p} 38$ kinase isoforms. J Biol Chem 281(10):6760-6767

15. Mendelsohn ME, Karas RH (1999) The protective effects of estrogen on the cardiovascular system. New Engl J Med 340(23):1801-1811

16. Petrov G, Regitz-Zagrosek V, Lehmkuhl E, Krabatsch T, Dunkel A, Dandel M, Dworatzek E, Mahmoodzadeh S, Schubert C, Becher E, Hampl H, Hetzer R (2010) Regression of myocardial hypertrophy after aortic valve replacement-faster in women than in men? Circulation 122(11 Suppl):S23-S28

17. Mahmoodzadeh S, Dworatzek E, Fritschka S, Pham TH, RegitzZagrosek V (2010) 17beta-Estradiol inhibits matrix metalloproteinase-2 transcription via MAP kinase in fibroblasts. Cardiovasc Res 85(4):719-728. doi:10.1093/cvr/cvp350

18. Hofmann U, Bonz A, Frantz S, Hu K, Waller C, Roemer K, Wolf J, Gattenlohner S, Bauersachs J, Ertl G (2012) A collagen alpha2(I) mutation impairs healing after experimental myocardial infarction. Am J Pathol 180(1):113-122. doi:10.1016/j. ajpath.2011.09.033 S0002-9440(11)00926-6 [pii]

19. Seeland U, Selejan S, Engelhardt S, Muller P, Lohse MJ, Bohm M (2007) Interstitial remodeling in beta1-adrenergic receptor transgenic mice. Basic Res Cardiol 102(2):183-193

20. Fielitz J, Hein S, Mitrovic V, Pregla R, Zurbrugg HR, Warnecke C, Schaper J, Fleck E, Regitz-Zagrosek V (2001) Activation of the cardiac renin-angiotensin system and increased myocardial collagen expression in human aortic valve disease. J Am Coll Cardiol 37(5):1443-1449

21. Pedram A, Razandi M, Lubahn D, Liu J, Vannan M, Levin ER (2008) Estrogen inhibits cardiac hypertrophy: role of estrogen receptor beta to inhibit calcineurin. Endocrinology 149(7):3361-3369

22. Skavdahl M, Steenbergen C, Clark J, Myers P, Demianenko T, Mao L, Rockman HA, Korach KS, Murphy E (2005) Estrogen receptor-beta mediates male-female differences in the development of pressure overload hypertrophy. Am J Physiol Heart Circ Physiol 288(2):H469-H476

23. Fliegner D, Schubert C, Penkalla A, Witt H, Kararigas G, Dworatzek E, Staub E, Martus P, Ruiz Noppinger P, Kintscher U, Gustafsson JA, Regitz-Zagrosek V (2010) Female sex and estrogen receptor $\{$ beta $\}$ attenuate cardiac remodeling and apoptosis in pressure overload. Am J Physiol Regul Integr Comp Physiol 298(6):R1597-R1606

24. Mahmoodzadeh S, Pham TH, Kuehne A, Fielitz B, Dworatzek E, Kararigas G, Petrov G, Davidson M, Regitz-Zagrosek V (2012) 17beta-Estradiol-induced interaction of ERalpha with NPPA regulates gene expression in cardiomyocytes. Cardiovasc Res 96(3):411-421. doi:10.1093/cvr/cvs281

25. Planavila A, Laguna JC, Vazquez-Carrera M (2005) Nuclear factor-kappaB activation leads to down-regulation of fatty acid oxidation during cardiac hypertrophy. J Biol Chem 280(17):17464-17471

26. Cavasin MA, Tao ZY, Yu AL, Yang XP (2006) Testosterone enhances early cardiac remodeling after myocardial infarction, causing rupture and degrading cardiac function. Am J Physiol Heart Circ Physiol 290(5):H2043-2050

27. Bernardo BC, Weeks KL, Pretorius L, McMullen JR (2010) Molecular distinction between physiological and pathological cardiac hypertrophy: experimental findings and therapeutic strategies. Pharmacol Therapeut 128(1):191-227. doi:10.1016/j. pharmthera.2010.04.005

28. Camper-Kirby D, Welch S, Walker A, Shiraishi I, Setchell KD, Schaefer E, Kajstura J, Anversa P, Sussman MA (2001) Myocardial Akt activation and gender: increased nuclear activity in females versus males. Circ Res 88(10):1020-1027 
29. McMullen JR, Amirahmadi F, Woodcock EA, Schinke-Braun M, Bouwman RD, Hewitt KA, Mollica JP, Zhang L, Zhang Y, Shioi T, Buerger A, Izumo S, Jay PY, Jennings GL (2007) Protective effects of exercise and phosphoinositide 3-kinase(p110alpha) signaling in dilated and hypertrophic cardiomyopathy. Proc Natl Acad Sci U S A 104(2):612-617

30. Hsieh YC, Choudhry MA, Yu HP, Shimizu T, Yang S, Suzuki T, Chen J, Bland KI, Chaudry IH (2006) Inhibition of cardiac PGC1alpha expression abolishes ER beta agonist-mediated cardioprotection following trauma-hemorrhage. Faseb J 20(8):1109-1117

31. Takano H, Komuro I (2009) Peroxisome proliferator-activated receptor gamma and cardiovascular diseases. Circ J 73(2):214-220

32. Nohammer C, Brunner F, Wolkart G, Staber PB, Steyrer E, Gonzalez FJ, Zechner R, Hoefler G (2003) Myocardial dysfunction and male mortality in peroxisome proliferator-activated receptor alpha knockout mice overexpressing lipoprotein lipase in muscle. Lab Invest 83(2):259-269

33. Loyer X, Damy T, Chvojkova Z, Robidel E, Marotte F, Oliviero P, Heymes C, Samuel JL (2007) 17beta-estradiol regulates constitutive nitric oxide synthase expression differentially in the myocardium in response to pressure overload. Endocrinology 148(10):4579-4584

34. Weinberg EO, Mirotsou M, Gannon J, Dzau VJ, Lee RT, Pratt RE (2003) Sex dependence and temporal dependence of the left ventricular genomic response to pressure overload. Physiol Genomics 12(2):113-127

35. Witt H, Schubert C, Jaekel J, Fliegner D, Penkalla A, Tiemann K, Stypmann J, Roepcke S, Brokat S, Mahmoodzadeh S, Brozova E, Davidson MM, Ruiz Noppinger P, Grohe C, Regitz-Zagrosek V (2008) Sex-specific pathways in early cardiac response to pressure overload in mice. J Mol Med 86(9):1013-1024
36. Kararigas G, Fliegner D, Gustafsson JA, Regitz-Zagrosek V (2011) Role of the estrogen/estrogen-receptor-beta axis in the genomic response to pressure overload-induced hypertrophy. Physiol Genomics 43(8):438-446. doi:10.1152/physiolgenomics. 00199.2010

37. Levy D, Larson MG, Vasan RS, Kannel WB, Ho KK (1996) The progression from hypertension to congestive heart failure. JAMA 275 (20):1557-1562

38. Liao Y, Cooper RS, Mensah GA, McGee DL (1995) Left ventricular hypertrophy has a greater impact on survival in women than in men. Circulation 92:805-810

39. Reis SE, Holubkov R, Young JB, White BG, Cohn JN, Feldman AM (2000) Estrogen is associated with improved survival in aging women with congestive heart failure: analysis of the vesnarinone studies. J Am Coll Cardiol 36(2):529-533

40. Rossouw JE, Prentice RL, Manson JE, Wu L, Barad D, Barnabei VM, Ko M, LaCroix AZ, Margolis KL, Stefanick ML (2007) Postmenopausal hormone therapy and risk of cardiovascular disease by age and years since menopause. JAMA 297(13):1465-1477

41. Regitz-Zagrosek V, Brokat S, Tschope C (2007) Role of gender in heart failure with normal left ventricular ejection fraction. Prog Cardiovasc Dis 49(4):241-251

42. Stangl V, Baldenhofer G, Knebel F, Zhang K, Sanad W, Spethmann S, Grubitzsch H, Sander M, Wernecke KD, Baumann G, Stang1 K, Laule M (2012) Impact of gender on three-month outcome and left ventricular remodeling after transfemoral transcatheter aortic valve implantation. Am J Cardiol 110(6):884-890. doi:10.1016/j.amjcard.2012.04.063 